\title{
Tin sulfide nanoparticles supported on activated carbon as an efficient and reusable Lewis acid catalyst for three-component one-pot synthesis of $4 \mathrm{H}$-pyrano[2,3-c]pyrazole derivatives
}

\author{
Nasir Iravani a,*, Mosadegh Keshavarz b,\#, Hossein Ali Shojaeian Kish a, Rasool Parandvarc \\ a Department of Chemistry, Faculty of Science, Gachsaran Branch, Islamic Azad University, Gachsaran, Iran \\ b Department of Gas and Petroleum, Yasouj University, Gachsaran, Iran \\ c Young and Reasearcers Elite, Gachsaran Branch, Islamic Azad University, Gachsaran, Iran
}

\section{A R T I C L E I N F O}

Article history:

Received 13 November 2014

Accepted 15 December 2014

Published 20 April 2015

Keywords:

Tin sulfide nanoparticle

Nanocomposite

Lewis acid catalyst

Heterogeneous catalyst

4H-pyrano[2,3-c]pyrazole

Multicomponent reaction

\begin{abstract}
A B S T R A C T
Tin sulfide nanoparticles (SnS-NPs) were prepared in aqueous solution at room temperature on the surface of activated carbon (AC) and were investigated using field-emission scanning electron microscopy (FE-SEM), transmission electron microscopy (TEM), X-ray diffraction, reflective ultraviolet-visible spectrophotometry, and spectrofluorimetry. Calculations based on the SEM and TEM images showed that the sizes of the SnS-NPs immobilized on the AC were 30-70 nm. The prepared nanocomposite was used as a heterogeneous Lewis acid catalyst for the three-components one-pot synthesis of $4 H$-pyrano[2,3-c]pyrazole derivatives in ethanol at $80^{\circ} \mathrm{C}$. The reactions were efficiently performed in the presence of the prepared catalyst in short reaction times, and gave the desired products in high yields. This catalyst can be easily recovered by simple filtration and recycled up to eight consecutive times without significant loss of its efficiency.
\end{abstract}

(C) 2015, Dalian Institute of Chemical Physics, Chinese Academy of Sciences. Published by Elsevier B.V. All rights reserved.

\section{Introduction}

Nanomaterials have been extensively studied because of their specific physical and chemical properties and potential applications in diverse areas [1]. These properties and potential applications have stimulated research into new methods for synthesizing these materials.

Recently, nanocatalysis has been introduced as a sustainable and competitive alternative to conventional catalysis; nanoparticles have high surface-to-volume ratios, and this increases their activities and selectivities, while conserving the basic features of a heterogeneous catalyst [2].

In recent years, much effort has been devoted to the preparation of various nanocrystals using a wide variety of methods, including electrode deposition [3], solvothermal routes [4,5], thermal decomposition [6], and chemical reduction [7]. These studies have led to the successful synthesis of many nanocrystals, including metals [8,9], oxides [10], and sulfides [11,12], and these have already been used as optoelectronic materials in sensors, laser materials, solar cells, and other devices.

Crystalline and partially crystalline nanosulfides have been extensively studied, because they have numerous potential applications as catalysts for use in coal liquefaction, solid lubricants, rechargeable batteries, solar cells, and coatings for microwave shields [13-16]. In particular, tin sulfide (SnS), which has a layered structure, is an important semiconductor, with an energy band gap of about $1.08 \mathrm{eV}$ [17]; it has potential applications in solar cells $[18,19]$ and photovoltaic devices [20].

\footnotetext{
* Corresponding author. Tel: +98-743-2334751; Fax: +98-743-2332003; E-mail: iravani.nasir@yahoo.com, iravaninasir56@gmail.com

\# Corresponding author. E-mail: chem.mosadegh@gmail.com

DOI: 10.1016/S1872-2067(14)60284-9 | http://www.sciencedirect.com/science/journal/18722067 | Chin. J. Catal., Vol. 36, No. 4, April 2015
} 
Pyrano[2,3-c]pyrazoles are important in medicinal chemistry as precursors to potential drugs, and they show a wide range of biological activities [21-23]. The development and improvement of synthetic approaches in this field using easily accessible and benign catalysts are therefore important. These compounds were first synthesized by Otto in 1974 by adding malononitrile to 4-arylidene-3-methyl-2-pyrazolin-5-one [24]. Several methods have been reported for the preparation of this class of compounds [25-43]. However, some of these methods suffer from drawbacks such as low yields, harsh reaction conditions, prolonged reaction times, and the use of hazardous and/or costly catalysts and solvents. The development of environmentally friendly approaches is therefore still needed. Recently, versatile heterogeneous catalysts produced by immobilization of nanoparticles on solid supports have provided a new and environmentally benign approach to synthetic organic chemistry [34,43-46]. Because of the importance of pyrano[2,3-c]pyrazoles, and as a part of our current studies on the synthesis of heterocyclic compounds [47-53], in this paper, we report the one-pot three-component synthesis of highly functionalized $4 H$-pyrano[2,3-c]pyrazoles $\mathbf{2 a - 2 s}$ by reactions between aldehydes 1, malononitrile, and 3-methyl-1-phenyl-2pyrazolin-5-one in ethanol at $80{ }^{\circ} \mathrm{C}$, catalyzed by a new, efficient, and reusable heterogeneous catalyst, namely $\mathrm{SnS}$ nanoparticles immobilized on activated carbon (SnS-NPs@AC; Scheme 1).

\section{Experimental}

All the starting materials were obtained from Fluka and were used without further purification.

\subsection{Preparation of SnS-NPs@AC}

The SnS-NPs@AC samples were prepared in aqueous solution at room temperature. In a typical procedure, $\mathrm{SnCl}_{2} \cdot 2 \mathrm{H}_{2} \mathrm{O}$ $(10 \mathrm{~mL}, 0.01 \mathrm{~mol} / \mathrm{L})$ was added to a three-necked flask containing $\mathrm{H}_{2} \mathrm{O}(50 \mathrm{~mL})$, and the $\mathrm{pH}$ was adjusted to 5.0 by drop-wise addition of a solution of $\mathrm{CH}_{3} \mathrm{COOH}(1 \mathrm{~mol} / \mathrm{L})$. The solution was saturated by $\mathrm{N}_{2}$ bubbling for about $20 \mathrm{~min}$; 2-(dimethylamino)ethanethiol $(10 \mathrm{~mL}, 0.05 \mathrm{~mol} / \mathrm{L})$ was then added to the $\mathrm{SnCl}_{2}$ solution under continuous vigorous stirring in a $\mathrm{N}_{2}$ atmosphere. After about $10 \mathrm{~min}$, thioacetamide $10 \mathrm{~mL}$, $0.01 \mathrm{~mol} / \mathrm{L}$ ) was added, and the solution was vigorously stirred under $\mathrm{N}_{2}$ for about $10 \mathrm{~min}$. Finally, the solution $\mathrm{pH}$ was adjusted to 6.0 by drop-wise addition of a solution of $\mathrm{CH}_{3} \mathrm{COOH}$ (1 $\mathrm{mol} / \mathrm{L})$. The solution was kept for $120 \mathrm{~min}$ at room temperature $\left(25^{\circ} \mathrm{C}\right)$. The solution turned light brown after $30 \mathrm{~min}$, indicating the initial formation of SnS-NPs, and remained optically clear.

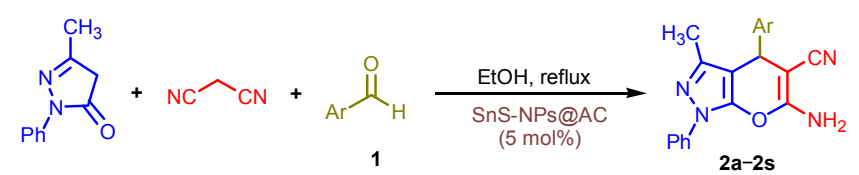

Scheme 1. Synthesis of 4H-pyrano[2,3-c]pyrazole derivatives using SnS-NPs@AC.
In the next step, the freshly prepared SnS-NP solution (500 $\mathrm{mL}, 1 \mathrm{mmol} / \mathrm{L})$ was mixed with AC (10 g) in a 1000-mL flask under magnetic stirring for up to $12 \mathrm{~h}$, resulting in deposition of SnS-NPs on the AC. The AC-supported SnS-NPs were filtered and thoroughly washed with doubly distilled water. The SnS-NPs in the initial undiluted filtrate solution were analyzed using UV-vis spectrophotometry. The SnS-NPs@AC sample was dried at $110{ }^{\circ} \mathrm{C}$ in an oven for $10 \mathrm{~h}$. A mortar was used to homogeneously grind the SnS-NPs@AC powders. The SnS-NPs@AC samples were stored in air at room temperature and used for further characterization.

\subsection{Characterization}

The SnS-NPs@AC morphology was examined using field-emission scanning electron microscopy (FE-SEM; Hitachi S-4160) under an accelerating voltage of $15 \mathrm{kV}$. Powder X-ray diffraction (XRD) patterns of the samples were obtained using an automated Philips X'Pert X-ray diffractometer with $\mathrm{Cu} K_{\alpha}$ radiation $(40 \mathrm{kV}$ and $30 \mathrm{~mA})$ at $2 \theta$ values of $10^{\circ}-70^{\circ}$. Absorption measurements and reflective ultraviolet-visible (UV-vis) absorption spectroscopy were performed with a PerkinElmer Lambda 25 spectrophotometer, using a quartz cell with an optical path of $1 \mathrm{~cm}$. The optical properties of the SnS-NPs were investigated based on photoluminescence measurements at room temperature, using a Cary Eclipse spectrofluorometer.

Fourier-transform infrared (FT-IR) spectra were recorded using a BOMEMMB-Series 1998 FT-IR spectrometer or a Bruker FT-IR spectrometer. ${ }^{1} \mathrm{H}$ and ${ }^{13} \mathrm{C}$ nuclear magnetic resonance (NMR) spectra were recorded using a Bruker DRX-400 AVANC instrument in DMSO- $d_{6}$ or $\mathrm{CDCl}_{3}$ at 400 and $100 \mathrm{MHz}$, respectively (results are reported as $\delta$ in parts per million, with coupling constants, $J$, in hertz), with tetramethylsilane as an internal standard. Melting points were determined using an SMP1 melting-point apparatus in open capillary tubes, and are uncorrected. All the $4 H$-pyrano[2,3-c]pyrazole derivatives were prepared using our procedure. The products were identified by comparison of their spectroscopic $\left({ }^{1} \mathrm{H}\right.$ and ${ }^{13} \mathrm{C}$ NMR, and IR), thin-layer chromatography (TLC), and physical data with those reported in the literature [25-42]; the data were in agreement with the proposed structures. All yields refer to isolated products.

\subsection{Determination of Sn content of SnS-NPs@AC}

SnS-NPs@AC (100 mg) was extracted with concentrated HCl $(5 \times 2 \mathrm{~mL})$ in a screw-capped vessel, followed by treatment with concentrated nitric acid ( $2 \mathrm{~mL}$ ) to digest the metal complex. The mixture was then transferred to a volumetric flask (100 mL), diluted 1:50 a second time, and analyzed using inductively coupled plasma atomic emission spectroscopy (ICP-AES). The $\mathrm{Sn}^{2+}$ concentration was determined from the atomic emissions $(430 \mathrm{~nm})$ by reference to a linear $(R=0.99)$ calibration curve for $\mathrm{Sn}\left(\mathrm{NO}_{3}\right)_{2}$ (1-4 ppm) prepared in a manner identical to the SnS-NPs@AC sample preparation. The ICP-AES analysis showed that the SnS content of the heterogeneous catalyst was $7.5 \mathrm{wt} \%$. The loading on the supported catalyst 
was therefore calculated to be $0.5 \mathrm{mmol} \mathrm{SnS} / \mathrm{g}$ of the prepared catalyst. The same procedure was used to measure leaching from the supported catalyst after eight consecutive runs.

\subsection{General procedure for synthesis of 4H-pyrano[2,3-c]pyrazoles}

3-Methyl-1-phenyl-2-pyrazolin-5-one (1 mmol), an aromatic aldehyde (1 mmol), and malononitrile (1 mmol) were placed in a round-bottomed flask containing ethanol $(5 \mathrm{~mL})$. SnS-NPs@AC (5 mol\%, $0.1 \mathrm{~g}$ ) was added to the mixture. The suspension was magnetically stirred under reflux conditions for an appropriate time (see Table 2). After completion of the reaction, which was monitored by TLC ( $n$-hexane:ethyl acetate $=3: 1$ ), the catalyst was filtered and washed with hot ethanol $(2$ $\times 5 \mathrm{~mL}$ ). The recovered catalyst was washed with acetone, dried, and stored for further similar consecutive runs. The filtrate mixture was recrystallized to provide pure crystals of 4H-pyrano[2,3-c]pyrazole derivatives. The products were known compounds and were characterized based on IR and NMR spectroscopic data. Their melting points (m.p.) were compared with reported values [25-42].

\subsection{Spectroscopic data for selected products}

6-Amino-4-(4-methoxyphenyl)-3-methyl-1-phenyl-1,4-dihydropyrano[2,3-c]pyrazole-5-carbonitrile (5e). Pale yellow powder. Yield: $0.32 \mathrm{~g}(89 \%)$. m.p. $241-243^{\circ} \mathrm{C}\left(242-243^{\circ} \mathrm{C}\right)$. IR (KBr): $v$ = 3394, 3325, 3059, 2975, 2193, 1661, 1597, 1515, 1397, 1258 $\mathrm{cm}^{-1}$. ${ }^{1} \mathrm{H}$ NMR: $\delta=1.78\left(3 \mathrm{H}, \mathrm{s}, \mathrm{CH}_{3}\right), 3.74\left(3 \mathrm{H}, \mathrm{s}, \mathrm{OCH}_{3}\right), 4.62$ $(1 \mathrm{H}, \mathrm{s}, \mathrm{CH}), 6.89(2 \mathrm{H}, \mathrm{d}, J=8.5 \mathrm{~Hz}, 2 \mathrm{CH}), 7.15(2 \mathrm{H}, \mathrm{s}, 2 \mathrm{CH}), 7.17$ $\left(2 \mathrm{H}, \mathrm{s}, \mathrm{NH}_{2}\right), 7.31(1 \mathrm{H}, \mathrm{t}, J=7.6 \mathrm{~Hz}, \mathrm{CH}), 7.49(2 \mathrm{H}, \mathrm{t}, J=7.6 \mathrm{~Hz}$, $2 \mathrm{CH}), 7.77(2 \mathrm{H}, \mathrm{d}, J=8.5 \mathrm{~Hz}, 2 \mathrm{CH})$ ppm. ${ }^{13} \mathrm{C}$ NMR: $\delta=12.6,35.9$, 55.1, 58.6, 98.9, 113.8, 119.9, 120.1, 126.2, 128.8, 129.4, 135.6, $137.5,145.4,158.2,159.3 \mathrm{ppm}$.

6-Amino-4-(3,4,5-trimethoxyphenyl)-3-methyl-1-phenyl-1,4dihydropyrano[2,3-c]pyrazole-5-carbonitrile (5f). Yellow powder. Yield: 0.36 g (86\%). m.p. $194-196^{\circ} \mathrm{C}\left(194-196{ }^{\circ} \mathrm{C}\right)$. IR (KBr): $v=3460,3325,3189,2940,2197,1657,1595,1521$, 1459, 1390, $1129 \mathrm{~cm}^{-1} .{ }^{1} \mathrm{H}$ NMR: $\delta=1.86\left(3 \mathrm{H}, \mathrm{s}, \mathrm{CH}_{3}\right), 3.65(3 \mathrm{H}$, s, $\left.\mathrm{OCH}_{3}\right), 3.73\left(6 \mathrm{H}, \mathrm{s}, 2 \mathrm{OCH}_{3}\right), 4.66(1 \mathrm{H}, \mathrm{s}, \mathrm{CH}), 6.55\left(2 \mathrm{H}, \mathrm{s}, \mathrm{NH}_{2}\right)$, $7.20(2 \mathrm{H}, \mathrm{s}, 2 \mathrm{CH}), 7.31(1 \mathrm{H}, \mathrm{t}, J=7.4 \mathrm{~Hz}, \mathrm{CH}), 7.49(2 \mathrm{H}, \mathrm{t}, J=7.6$ $\mathrm{Hz}, 2 \mathrm{CH}), 7.78(2 \mathrm{H}, \mathrm{d}, J=7.6 \mathrm{~Hz}, 2 \mathrm{CH}) \mathrm{ppm} .{ }^{13} \mathrm{C}$ NMR: $\delta=12.8$, 37.0 , 55.9, 57.9, 60.0, 98.4, 105.0, 119.9, 120.1, 126.2, 129.4, $136.4,137.6,139.3,143.8,145.4,152.9,159.6 \mathrm{ppm}$.

6-Amino-4-(3-nitrophenyl)-3-methyl-1-phenyl-1,4-dihydropyrano[2,3-c]pyrazole-5-carbonitrile (5g). Yellow powder. Yield: 0.33 g (88\%). m.p. $190-192{ }^{\circ} \mathrm{C}\left(189-191{ }^{\circ} \mathrm{C}\right)$. IR (KBr): $v=$ 3436, 3296, 3098, 2190, 1651, 1589, 1517, 1446, 1386, 1349, 1258, $1119 \mathrm{~cm}^{-1} .{ }^{1} \mathrm{H}$ NMR: $\delta=1.90\left(3 \mathrm{H}, \mathrm{s}, \mathrm{CH}_{3}\right), 4.81(1 \mathrm{H}, \mathrm{s}, \mathrm{CH})$, $4.83\left(2 \mathrm{H}, \mathrm{s}, \mathrm{NH}_{2}\right), 7.36-7.37(1 \mathrm{H}, \mathrm{m}, \mathrm{CH}), 7.48-7.51(2 \mathrm{H}, \mathrm{m}$, $2 \mathrm{CH}), 7.56-7.59(1 \mathrm{H}, \mathrm{m}, \mathrm{CH}), 7.66-7.67(3 \mathrm{H}, \mathrm{m}, 3 \mathrm{CH}), 8.13(1 \mathrm{H}$, s, CH), $8.19\left(1 \mathrm{H}, \mathrm{d}, 3_{\mathrm{HH}}=7.2 \mathrm{~Hz}, \mathrm{CH}\right) \mathrm{ppm} .{ }^{13} \mathrm{C}$ NMR: $\delta=13.0$, $36.8,57.6,98.0,120.3,120.5,122.7,126.7,129.7,130.7,135.2$, $137.9,144.5,145.6,146.4,184.4,160.3 \mathrm{ppm}$.

6-Amino-4-(4-nitrophenyl)-3-methyl-1-phenyl-1,4-dihydropyrano[2,3-c]pyrazole-5-carbonitrile (5h). Yellow powder. Yield:
0.34 g (90\%). m.p. $196-198{ }^{\circ} \mathrm{C}\left(197-198{ }^{\circ} \mathrm{C}\right)$. IR (KBr): $v=$ 3391, 3312, 3196, 2923, 2201, 1651, 1590, 1515, 1452, 1393, 1343, $1261 \mathrm{~cm}^{-1}$. ${ }^{1} \mathrm{H}$ NMR: $\delta=1.80\left(3 \mathrm{H}, \mathrm{s}, \mathrm{CH}_{3}\right), 4.93(1 \mathrm{H}, \mathrm{s}, \mathrm{CH})$, $7.34\left(2 \mathrm{H}, \mathrm{t}, 3_{\mathrm{HH}}=7.6 \mathrm{~Hz}, 2 \mathrm{CH}\right), 7.69\left(2 \mathrm{H}, \mathrm{s}, \mathrm{NH}_{2}\right), 7.51\left(2 \mathrm{H}, \mathrm{t}, 3_{\mathrm{HH}}\right.$ $=8.4 \mathrm{~Hz}, 2 \mathrm{CH}), 7.59\left(2 \mathrm{H}, \mathrm{d}, 33_{\mathrm{HH}}=8.8 \mathrm{~Hz}, 2 \mathrm{CH}\right), 7.80\left(2 \mathrm{H}, \mathrm{d}, 33_{\mathrm{HH}}\right.$ $=8.4 \mathrm{~Hz}, 2 \mathrm{CH}), 8.24\left(2 \mathrm{H}, \mathrm{d},{ }^{3} \mathrm{JHH}=8.8 \mathrm{~Hz}, 2 \mathrm{CH}\right) \mathrm{ppm} .{ }^{13} \mathrm{C}$ NMR: $\delta$ $=13.6,37.4,57.9,98.7,120.8,121.2,124.9,127.4,130.3,130.4$, $138.5,145.1,146.2,147.7,152.3,160.8 \mathrm{ppm}$.

6-Amino-4-(2-chlorophenyl)-3-methyl-1-phenyl-1,4-dihydropyrano[2,3-c]pyrazole-5-carbonitrile (5i). Yellow powder. Yield: 0.32 g (89\%). m.p. $142-144{ }^{\circ} \mathrm{C}\left(140-142{ }^{\circ} \mathrm{C}\right)$. IR (KBr): $v$ $=3379,3191,3064,2969,2188,1661,1592,1513,1395,1263$, $1126 \mathrm{~cm}^{-1}$. ${ }^{1} \mathrm{H}$ NMR: $\delta=1.89\left(3 \mathrm{H}, \mathrm{s}, \mathrm{CH}_{3}\right), 4.73\left(2 \mathrm{H}, \mathrm{s}, \mathrm{NH}_{2}\right), 5.31$ $(1 \mathrm{H}, \mathrm{s}, \mathrm{CH}), 7.22-7.31(3 \mathrm{H}, \mathrm{m}, 3 \mathrm{CH}), 7.33-7.34(1 \mathrm{H}, \mathrm{m}, \mathrm{CH})$, 7.39-7.71 (1H, m, CH), 7.46-7.49 (2H, m, 2CH), 7.65-7.67 (2H, m, 2CH) ppm. ${ }^{13} \mathrm{C}$ NMR: $\delta=13.8,35.1,63.3,99.2,120.0,122.3$, 127.9, 128.7, 129.9, 130.4, 131.1, 131.8, 134.5, 138.6, 140.3, 145.1, 147.3, $160.1 \mathrm{ppm}$.

6-Amino-4-(4-chlorophenyl)-3-methyl-1-phenyl-1,4-dihydropyrano[2,3-c]pyrazole-5-carbonitrile (5j). Yellow powder. Yield: $0.31 \mathrm{~g}$ (87\%). m.p. $174-176^{\circ} \mathrm{C}\left(175-178{ }^{\circ} \mathrm{C}\right)$. IR (KBr): $v$ $=3459,3326,3199,2923,2198,1658,1594,1521,1495,1470$, 1395, $1269 \mathrm{~cm}^{-1} .{ }^{1} \mathrm{H}$ NMR: $\delta=1.77\left(3 \mathrm{H}, \mathrm{s}, \mathrm{CH}_{3}\right), 5.15(1 \mathrm{H}, \mathrm{s}, \mathrm{CH})$, $7.31\left(1 \mathrm{H}, \mathrm{t},{ }^{3} \mathrm{JHH}_{\mathrm{HH}}=7.6 \mathrm{~Hz}, \mathrm{CH}\right), 7.32-7.34(2 \mathrm{H}, \mathrm{m}, 2 \mathrm{CH}), 7.37(2 \mathrm{H}$, s, $\left.\mathrm{NH}_{2}\right), 7.41\left(1 \mathrm{H}, \mathrm{d}, 3_{\mathrm{HH}}=7.6 \mathrm{~Hz}, \mathrm{CH}\right), 7.43\left(1 \mathrm{H}, \mathrm{d}, 3 \mathrm{~J}_{\mathrm{HH}}=7.6 \mathrm{~Hz}\right.$, $\mathrm{CH}), 7.46-7.51(2 \mathrm{H}, \mathrm{m}, 2 \mathrm{CH}), 7.61\left(1 \mathrm{H}, \mathrm{d}, 33_{\mathrm{HH}}=7.6 \mathrm{~Hz}, \mathrm{CH}\right)$, 7.76-7.78 (2H, m, 2CH) ppm. ${ }^{13} \mathrm{C}$ NMR: $\delta=12.4,33.6,56.2,97.3$, 119.6, 120.1, 126.2, 128.1, 128.9, 129.4, 132.6, 133.1, 137.4, $139.3,144.3,144.8,159.9 \mathrm{ppm}$.

6-Amino-4-(2,4-dichlorophenyl)-3-methyl-1-phenyl-1,4-dihydropyrano[2,3-c]pyrazole-5-carbonitrile (5l). Yellow powder. Yield: 0.36 g (90\%). m.p. $180-182{ }^{\circ} \mathrm{C}\left(182-184{ }^{\circ} \mathrm{C}\right)$. IR (KBr): $v$ $=3455,3324,3060,2918,2197,1660,1588,1519,1394,1267$, 1182, $1125 \mathrm{~cm}^{-1} .{ }^{1} \mathrm{H}$ NMR: $\delta=1.91\left(3 \mathrm{H}, \mathrm{s}, \mathrm{CH}_{3}\right), 4.74(2 \mathrm{H}, \mathrm{s}$, $\left.\mathrm{NH}_{2}\right), 5.28(1 \mathrm{H}, \mathrm{s}, \mathrm{CH}), 7.14-7.16(1 \mathrm{H}, \mathrm{m}, \mathrm{CH}), 7.25-7.27(1 \mathrm{H}, \mathrm{m}$, CH), 7.34-7.36 (1H, m, CH), 7.44-7.48 (3H, m, 3CH), $7.65(2 \mathrm{H}$, m, 2CH) ppm. ${ }^{13} \mathrm{C}$ NMR: $\delta=14.1,38.1,65.2,99.7,115.7,122.3$, 127.8, 127.9, 128.8, 130.4, 138.7, 144.9, $149.2 \mathrm{ppm}$.

6-Amino-4-(4-cyanophenyl)-3-methyl-1-phenyl-1,4-dihydropyrano[2,3-c]pyrazole-5-carbonitrile (5n). Pale yellow powder. Yield: 0.30 g (85\%). m.p. $215-217^{\circ} \mathrm{C}\left(217-218^{\circ} \mathrm{C}\right)$. IR (KBr): $v$ = 3396, 3307, 3197, 2986, 2233, 2187, 1652, 1590, 1513, 1449, 1385, 1262, $1120 \mathrm{~cm}^{-1} .{ }^{1} \mathrm{H}$ NMR: $\delta=1.89\left(3 \mathrm{H}, \mathrm{s}, \mathrm{CH}_{3}\right), 4.75(1 \mathrm{H}$, s, CH), $4.79\left(2 \mathrm{H}, \mathrm{s}, \mathrm{NH}_{2}\right), 7.35-7.37(1 \mathrm{H}, \mathrm{m}, \mathrm{CH}), 7.39-7.41(2 \mathrm{H}$, m, 2CH), 7.47-7.50 (2H, m, 2CH), 7.64-7.69 (4H, m, 4CH) ppm. ${ }^{13} \mathrm{C}$ NMR: $\delta=14.1,38.7,61.1,63.6,98.3,112.8,119.7,122.5$, 128.2, 129.9, 130.5, 133.9, 138.5, 147.2, 148.4, 159.6 ppm.

6-Amino-4-(4-bromophenyl)-3-methyl-1-phenyl-1,4-dihydropyrano[2,3-c]pyrazole-5-carbonitrile (5q). White powder. Yield: 0.36 g (89\%). m.p. $184-186^{\circ} \mathrm{C}\left(184-186^{\circ} \mathrm{C}\right)$. IR (KBr): $v$ = 3450, 3330, 2949, 2198, 1661, 1589, 1515, 1452, 1393, 1259, $1175 \mathrm{~cm}^{-1}$. ${ }^{1} \mathrm{H}$ NMR: $\delta=1.90\left(3 \mathrm{H}, \mathrm{s}, \mathrm{CH}_{3}\right), 4.64-4.69(3 \mathrm{H}, \mathrm{m}, \mathrm{CH}$, $\left.\mathrm{NH}_{2}\right), 7.13-7.15$ (2H, m, 2CH), 7.33-7.35 (H, m, CH), 7.48-7.50 (4H, m, 4CH), 7.64-7.66 (2H, m, 2CH) ppm. ${ }^{13} \mathrm{C}$ NMR: $\delta=13.1$, 36.7, 58.2, 98.6, 120.4, 120.5, 120.6, 126.7, 129.9, 129.8, 130.5, $131.9,137.9,143.6,144.4,1415.7,159.9 \mathrm{ppm}$. 


\section{Results and discussion}

\subsection{Preparation of SnS-NPs@AC catalyst}

The SnS-NPs@AC catalyst was easily prepared using a two-step procedure. The AC was refluxed with a nitric acid solution for $12 \mathrm{~h}$ and washed with deionized water until the $\mathrm{pH}$ was 6-7 and then dried in an oven overnight under vacuum. The oxidized AC was uniformly mixed with a freshly prepared SnS-NP solution (prepared by addition of 2-(dimethylamino)ethanethiol and thioacetamide to an aqueous solution of $\mathrm{SnCl}_{2} \cdot 2 \mathrm{H}_{2} \mathrm{O}$ in a $\mathrm{N}_{2}$ atmosphere). Finally, the mixture was stirred and maintained at room temperature for several hours, resulting in direct growth of SnS-NPs@AC in the solution. The SnS-NPs@AC was filtered, washed with doubly-distilled water, and dried at $110^{\circ} \mathrm{C}$. This immobilization procedure is quick and simple, uses readily available $\mathrm{AC}$, and does not require catalyst modification to enable immobilization.

\subsection{Characterization of SnS-NPs@AC catalyst}

The optical properties of the SnS-NPs@AC were determined. Figure 1 shows the room-temperature UV-Vis absorption spectra for the SnS-NPs. The absorption edges of the samples are observed at lower wavelengths, signifying a blue shift. The value of the energy band gap, $E_{\mathrm{g}}$, was calculated from the UV-vis spectrum by plotting $(\alpha h v)^{2}$ versus $h v$ (inset) [54] where $\alpha, h$, and $v$ signify the absorption coefficient, Planck's constant, and frequency, respectively. It is clear from Fig. 1 that the band gap changed from 1.83 to $2.26 \mathrm{eV}$ as the nanocrystal size decreased. In a typical synthesis, small particles (i.e., nuclei) appeared at $\mathrm{pH} 6.0$ and $25^{\circ} \mathrm{C}$. As the nanoparticles grew, the number of particles quickly increased to a maximum and then decreased during further growth. Significantly, some of the particles formed in the initial stage disappeared after growth for $2 \mathrm{~h}$, but the size distribution of the nanoparticles continued to narrow throughout the synthesis.

The crystallinity of the SnS-NPs on the AC surface was investigated using XRD; the results are shown in Fig. 2. The five

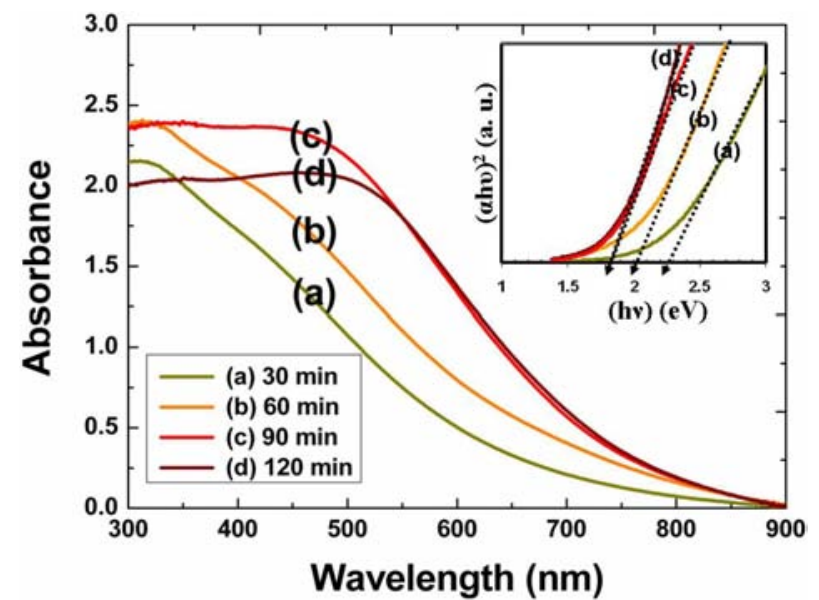

Fig. 1. Temporal evolution of absorption spectrum and plot of $(\alpha h v)^{2}$ versus $h v$ (inset) of nanoparticles during SnS-NP synthesis at pH 6.0 and $25^{\circ} \mathrm{C}$.

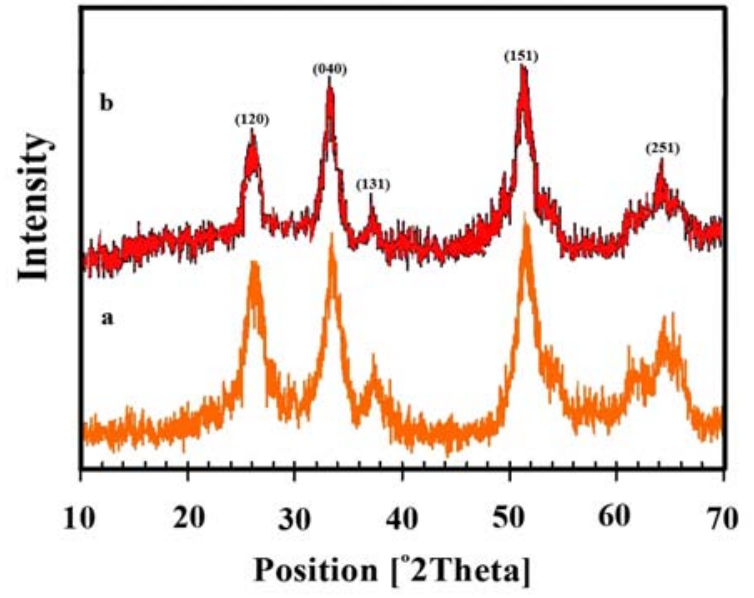

Fig. 2. XRD patterns of (a) fresh SnS-NPs@AC and (b) used SnS-NPs@AC after the eighth run.

broad peaks observed at around $26.20^{\circ}, 31.45^{\circ}, 37.86^{\circ}, 51.25^{\circ}$, and $64.40^{\circ}$ indicate that the Sn-NPs have an orthorhombic lattice structure (mineral herzenbergite) [55]. The broadening of the XRD peaks is associated with SnS-NP formation. The average nanocrystallite size $(D)$ was calculated using Scherrer's formula [56] $D=K \lambda / \beta \cos \theta$, where $K(=0.89)$ is the shape factor, $\lambda$ is the wavelength of $\mathrm{Cu} K_{\alpha}$ radiation $(0.15406 \mathrm{~nm}), \theta$ is the Bragg angle, and $\beta$ is the experimental full-width at half-maximum of the diffraction peak (radians). The estimated average nanoparticle size was about $64 \mathrm{~nm}$. It also shows that the patterns of the fresh and reused catalysts are the same; this indicates that the SnS-NPs are retained on the AC surface after eight runs.

The FE-SEM images of the AC surface, SnS-NPs, and SnS-NPs@AC are shown in Fig. 3. It can be seen that the AC surface morphology is homogeneous and relatively smooth and that the SnS-NPs deposited on the AC are highly dispersed on the surface, without any aggregation, and have an approximately uniform size distribution. The size and microstructure of the SnS-NPs were also examined using FE-SEM. The morphology of the SnS-NPs can be clearly observed (Fig. 3(c)).

TEM images of the fresh and reused catalysts are shown in Fig. 4. It shows that the size of the nanoparticles immobilized on the AC did not significantly change from the first to the eighth runs. Moreover, no nanoparticle aggregation is seen after the eighth run.

The SnS-NP sizes estimated from FE-SEM and TEM images were of 40-90 and 30-70 $\mathrm{nm}$, respectively, which are in accordance with the XRD results $(64 \mathrm{~nm})$.

\subsection{Optimization of reaction conditions}

There are no previous reports of the use of SnS or its supported form as a catalyst in organic synthesis. We were therefore interested in investigating the catalytic activity of the prepared SnS-NPs@AC as a new heterogeneous catalyst for the synthesis of $4 H$-pyrano[2,3-c]pyrazole derivatives. The reaction of benzaldehyde, malononitrile, and 3-methyl-1-phenyl-2pyrazolin-5-one was selected as a model reaction to establish 

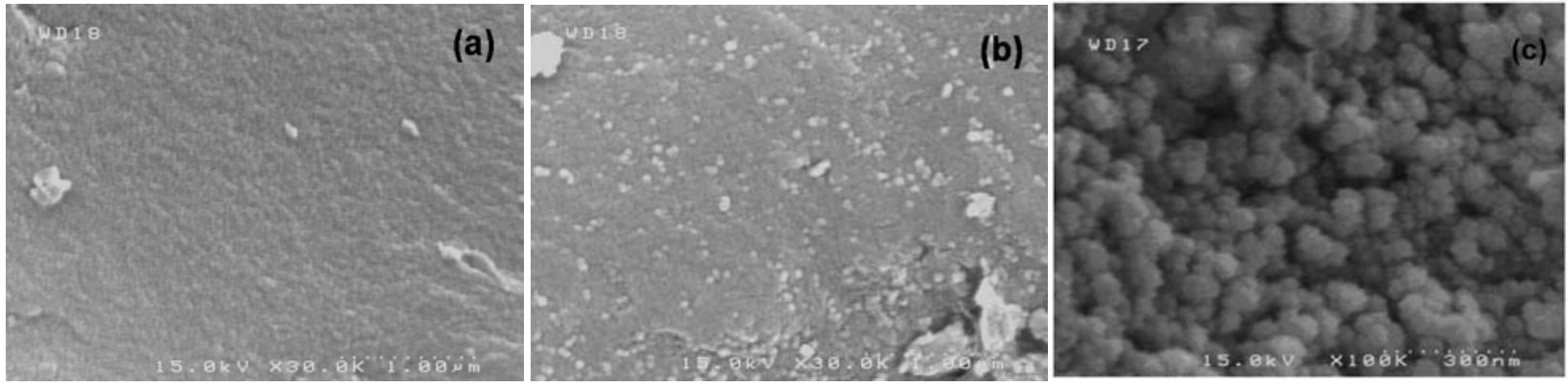

Fig. 3. FE-SEM images of AC (a), SnS-NPs@AC (b), and SnS-NPs (c).
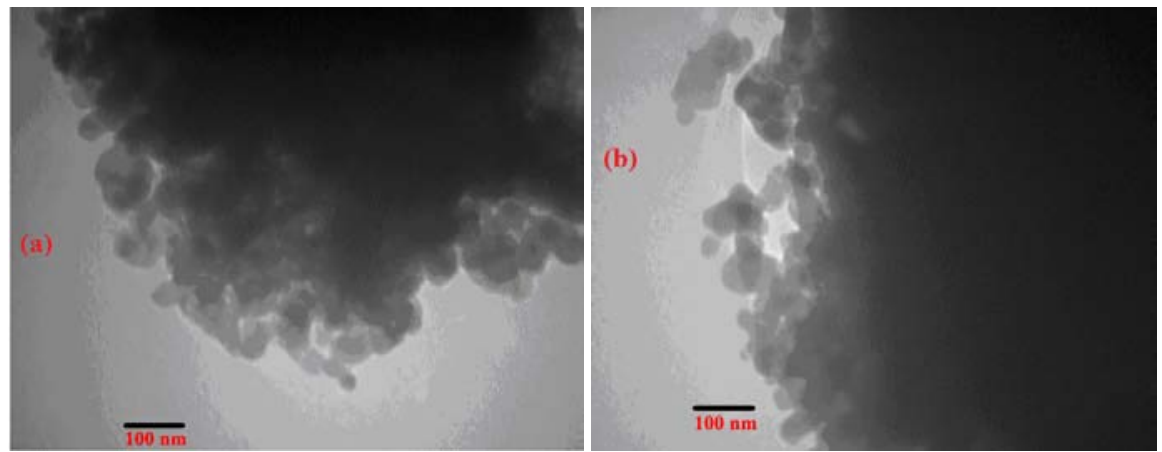

Fig. 4. TEM images of (a) fresh SnS-NPs@AC and (b) used SnS-NPs@AC after the eighth run.

the reaction conditions, and the effects of different molar ratios of the SnS-NPs@AC and free SnS-NPs were studied under various conditions (Table 1). The green solvents poly(ethylene glycol) (PEG) 300, ethanol, $\mathrm{H}_{2} \mathrm{O}$, ethanol $/ \mathrm{H}_{2} \mathrm{O}$, and $\mathrm{PEG}$ $300 / \mathrm{H}_{2} \mathrm{O}$ were examined. Ethanol, which clearly gave the fastest reaction rate and highest yield, was chosen as the solvent. A comparison of the yields and reaction rates with and without SnS-NPs clearly showed the importance of the catalyst (entry 1 versus entries 2-6).

The yield smoothly increased with increasing catalyst loading up to $5 \mathrm{~mol} \%$; the use of a larger amount of catalyst (10 mol\%) did not improve the yield, and lower amounts of catalyst led to decreased yields. Moreover, the yield increased slightly when the same molar ratio of SnS-NPs@AC was used instead of the optimum neat SnS-NPs (Table 1, entries 3 and 6). SnS-NPs@AC was therefore the preferred form of the catalyst, because it has advantages such as a simple recovery process, higher yields, and less product contamination compared with neat SnS-NPs.

The reactions of 3-methyl-1-phenyl-2-pyrazolin-5-one, malononitrile, and various aromatic aldehydes were explored using 5 mol\% SnS-NPs@AC in ethanol under reflux conditions (Scheme 1, Table 2). All the products were cleanly isolated by simple filtration and recrystallization from hot ethanol. As

\section{Table 1}

Catalytic activities of SnS-NPs and SnS-NPs@AC in synthesis of 4H-pyrano[2,3-c]pyrazole derivatives under various conditions.

\begin{tabular}{|c|c|c|c|c|c|}
\hline Entry & Solvent & Temperature $\left({ }^{\circ} \mathrm{C}\right)$ & Catalyst & Time (min) & Yield a (\%) \\
\hline 1 & Ethanol & Reflux & No catalyst & 60 & 18 \\
\hline 2 & Ethanol & Reflux & SnS nanoparticles (2 mol\%, $0.003 \mathrm{~g}$ ) & 60 & 66 \\
\hline 3 & Ethanol & Reflux & SnS nanoparticles (5 mol\%, $0.008 \mathrm{~g}$ ) & 20 & 86 \\
\hline 4 & Ethanol & Reflux & SnS nanoparticles (10 mol\%, $0.015 \mathrm{~g}$ ) & 20 & 87 \\
\hline 5 & Ethanol & Reflux & SnS-NPs@AC (2 mol\%, 0.04 g) & 20 & 70 \\
\hline 6 & Ethanol & Reflux & SnS-NPs@AC (5 mol\%, 0.1 g) & 20 & 91 \\
\hline 7 & $\mathrm{EtOH} / \mathrm{H}_{2} \mathrm{O}(1: 1)$ & 80 & SnS-NPs@AC (5 mol\%, 0.1 g) & 20 & 78 \\
\hline 8 & $\mathrm{H}_{2} \mathrm{O}$ & Reflux & SnS-NPs@AC (5 mol\%, 0.1 g) & 30 & 70 \\
\hline 9 & PEG300 & 60 & SnS-NPs@AC (5 mol\%, 0.1 g) & 30 & 64 \\
\hline 10 & PEG300/ $\mathrm{H}_{2} \mathrm{O}(1: 1)$ & 80 & SnS-NPs@AC (5 mol\%, 0.1 g) & 30 & 78 \\
\hline
\end{tabular}

Reaction conditions: benzaldehyde ( $1 \mathrm{mmol})$, malononitrile $(1 \mathrm{mmol}), 3$-methyl-1-phenyl-2-pyrazolin-5-one (1 mmol), solvent (10 ml).

aYields refer to isolated and pure products. 
shown in Table 2, in all cases, aromatic aldehydes substituted with either electron-donating or electron-withdrawing groups smoothly underwent the reaction and gave the target products in good to excellent yields (2a-2s). It should be mentioned that our efforts to synthesize $4 H$-pyrano[2,3-c]pyrazoles using aliphatic aldehydes were unsuccessful, probably because of aldehyde enolization during the reaction.

A plausible mechanism for this reaction is shown in Scheme 2. Compound $\mathbf{2}$ is formed by condensation of the aromatic aldehyde with malononitrile to produce alkylidenemalononitrile 7. In the presence of SnS-NPs@AC, 3-methyl-1-phenyl-2-pyra- zolin-5-one undergoes proton transfer via tautomerization to give intermediate $\mathbf{8}$. The reaction of intermediates $\mathbf{7}$ and $\mathbf{8}$ yields intermediate $\mathbf{9}$. This intermediate undergoes proton transfer and subsequent intramolecular cyclization to form the heterocyclic intermediate 10, which generates $\mathbf{2}$ by proton transfer via tautomerization.

It is also worth noting that SnS-NPs@AC does not suffer from mechanical degradation after several runs. For a good, efficient heterogeneous catalyst, the supported catalyst should not leach into the reaction mixture, and the recyclability of the supported catalyst is also important. To investigate these

Table 2

Synthesis of 4H-pyrano[2,3-c]pyrazole derivatives catalyzed by SnS-NPs@AC (Scheme 1).

\begin{tabular}{|c|c|c|c|c|c|c|}
\hline \multirow{2}{*}{ Entry } & \multirow{2}{*}{$\mathrm{Ar}$} & \multirow{2}{*}{ Product } & \multirow{2}{*}{ Time (min) } & \multirow{2}{*}{ 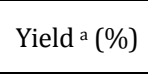 } & \multicolumn{2}{|c|}{ m.p. $\left({ }^{\circ} \mathrm{C}\right)$} \\
\hline & & & & & Found & Reported \\
\hline 1 & $\mathrm{C}_{6} \mathrm{H}_{5}$ & $2 a$ & 20 & 91 & $168-170$ & 169-171 \\
\hline 2 & 4- $\mathrm{PhC}_{6} \mathrm{H}_{4}$ & $2 b$ & 25 & 88 & 190-192 & 190-192 \\
\hline 3 & $4-\mathrm{MeC}_{6} \mathrm{H}_{4}$ & $2 c$ & 25 & 87 & $159-161$ & $158-160$ \\
\hline 4 & 4- $\mathrm{CHOC}_{6} \mathrm{H}_{4}$ & 2d & 25 & 87 & $235-237$ & $234-236$ \\
\hline 5 & $4-\mathrm{MeOC}_{6} \mathrm{H}_{4}$ & $2 e$ & 25 & 89 & $241-243$ & $242-243$ \\
\hline 6 & $3,4,5-(\mathrm{MeO})_{3} \mathrm{C}_{6} \mathrm{H}_{2}$ & $2 f$ & 25 & 86 & 194-196 & 194-196 \\
\hline 7 & $3-\mathrm{NO}_{2} \mathrm{C}_{6} \mathrm{H}_{4}$ & $2 g$ & 15 & 88 & 190-192 & 189-191 \\
\hline 8 & $4-\mathrm{NO}_{2} \mathrm{C}_{6} \mathrm{H}_{4}$ & $2 \mathrm{~h}$ & 18 & 90 & 196-198 & 197-198 \\
\hline 9 & $2-\mathrm{ClC}_{6} \mathrm{H}_{4}$ & $2 \mathbf{i}$ & 18 & 89 & $142-144$ & $140-142$ \\
\hline 10 & $4-\mathrm{ClC}_{6} \mathrm{H}_{4}$ & $2 \mathbf{j}$ & 15 & 87 & $174-176$ & $175-178$ \\
\hline 11 & $3-\mathrm{ClC}_{6} \mathrm{H}_{4}$ & $2 \mathbf{k}$ & 20 & 91 & $159-161$ & $158-161$ \\
\hline 12 & $2,4-(\mathrm{Cl})_{2} \mathrm{C}_{6} \mathrm{H}_{3}$ & 21 & 15 & 90 & $180-182$ & $182-184$ \\
\hline 13 & $4-\mathrm{FC}_{6} \mathrm{H}_{4}$ & $2 m$ & 18 & 87 & $171-173$ & $170-172$ \\
\hline 14 & $4-\mathrm{CNC}_{6} \mathrm{H}_{4}$ & $2 n$ & 15 & 85 & $215-217$ & $217-218$ \\
\hline 15 & $4-\mathrm{OHC}_{6} \mathrm{H}_{4}$ & 20 & 25 & 89 & $205-207$ & $206-207$ \\
\hline 16 & $2-\mathrm{OHC}_{6} \mathrm{H}_{4}$ & $2 p$ & 20 & 92 & $206-208$ & 207-209 \\
\hline 17 & $4-\mathrm{BrC}_{6} \mathrm{H}_{4}$ & $2 q$ & 15 & 89 & $184-186$ & 184-186 \\
\hline 18 & $4-\mathrm{CNC}_{6} \mathrm{H}_{4}$ & $2 r$ & 15 & 90 & $217-220$ & $217-219$ \\
\hline 19 & 2-Naphthyl & $2 s$ & 25 & 90 & $178-181$ & $178-180$ \\
\hline
\end{tabular}

Reaction conditions: Aromatic aldehyde (1 mmol), malononitrile (1 mmol), 3-methyl-1-phenyl-2-pyrazolin-5-one (1 mmol), SnS-NPs@AC (5 mol \%, $0.10 \mathrm{~g})$, EtOH $(10 \mathrm{ml})$, reflux.

aYields refer to isolated and pure products.

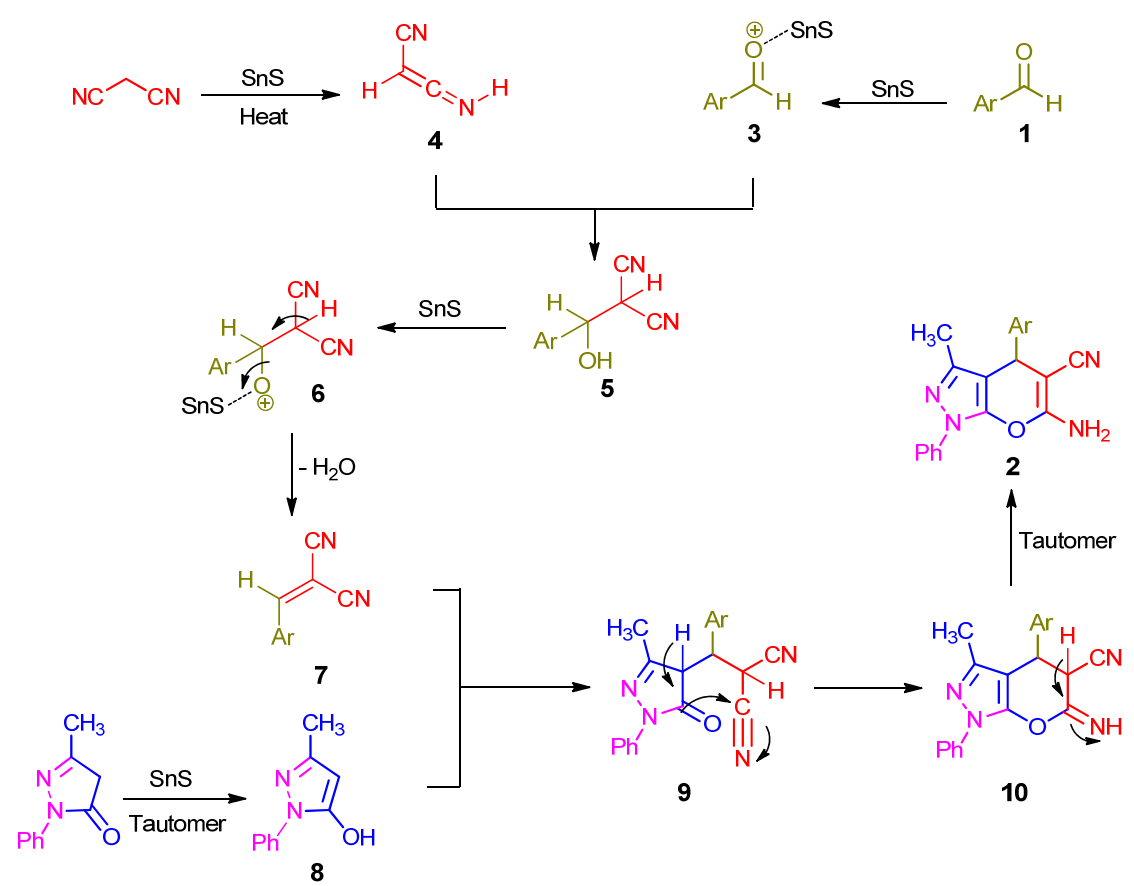

Scheme 2. Plausible mechanism for synthesis of 4H-pyrano[2,3-c]pyrazole derivatives using SnS-NPs@AC. 


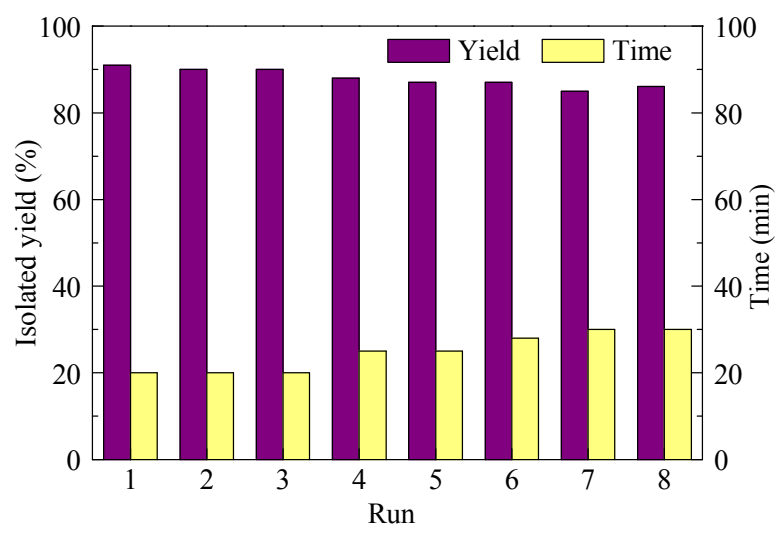

Fig. 5. Recyclability of SnS-NPs@AC.

properties for our catalyst, the reaction of 3-methyl-1-phenyl2-pyrazolin-5-one, benzaldehyde, and malononitrile in ethanol was again selected as a model reaction (Fig. 5). After completion of the reaction, the mixture was filtered, and complete separation of the product from the surface of the catalyst was achieved by washing the catalyst with hot ethanol $(2 \times 5 \mathrm{~mL})$. Finally, the recovered catalyst was washed with acetone and dried before use for seven consecutive runs. Almost consistent activity was observed over seven consecutive runs. From Fig. 5, it can be seen that SnS-NPs@AC can be reused for up to eight runs without catalyst reloading. The yield difference between the first and eighth runs was only $5 \%$, which indicates that the catalytic efficiency is almost completely maintained during eight consecutive runs.

Next, we checked the leaching of SnS into the reaction mixture from the AC support using ICP-AES. The difference between the $\mathrm{Sn}^{2+}$ content of the fresh catalyst and the reused catalyst (after the eighth run) was only 3\%, which indicates negligible leaching of $\mathrm{SnS}$ into the reaction mixture. Table 3 shows the efficiency and superiority of the present catalyst compared with some previously reported catalysts.

\section{Conclusions}

SnS-NPs supported on AC were prepared using a simple two-step procedure and were thoroughly characterized. The results showed that the size of the SnS-NPs immobilized on AC was $30-70 \mathrm{~nm}$. The catalytic efficiency of the prepared catalyst in the synthesis of $4 H$-pyrano[2,3-c]pyrazole derivatives was investigated. In the presence of SnS-NPs@AC, all the reactions had short reaction times and gave high yields. Nanosized particles, with a high surface-to-volume ratio, simple workup and recovery, and reusability in up to eight consecutive runs, with very low leaching, make this a new, efficient, and superior catalyst superior for the synthesis of $4 H$-pyrano[2,3-c]pyrazole derivatives. Further catalytic uses of SnS-NPs@AC are under investigation in our laboratories.

\section{Acknowledgments}

We are grateful to Islamic Azad University, Gachsaran Branch and the Research Council of Yasouj University for financial support.

\section{References}

[1] Buzea C, Pacheco I I, Robbie K. Biointerphases, 2007, 2(4): MR17

[2] Astruc D. Nanoparticles and Catalysis. Weinheim: Wiley-VCH, 2008

[3] Tian N, Zhou Z Y, Yu N F, Wang L Y, Sun S G. J Am Chem Soc, 2010, 132: 7580

[4] Zhang C, Kang Z H, Shen E H, Wang E B, Gao L, Luo F, Tian C G, Wang C L, Lan Y, Li J X, Cao X J.J Phys Chem B, 2006, 110: 184

[5] Li Z H, Zeng J H, Li Y D. Small, 2007, 3: 438

[6] Chen L J, Li L P, Li G S. J Alloys Compd, 2008, 464: 532

[7] Cheng F Y, Shen J, Peng B, Pan Y D, Tao Z L, Chen J. Nat Chem, 2011, 3: 79

[8] Xia Y N, Xiong Y J, Lim B, Skrabalak S E. Angew Chem Int Ed, 2009, 48: 60

[9] Xiong Y J, Xia Y N. Adv Mater, 2007, 19: 3385

[10] Kaneko K, Inoke K, Freitag B, Hungria A B, Midgley P A, Hansen T W, Zhang J, Ohara S, Adschiri T. Nano Lett, 2007, 7: 421

[11] Wu Y, Wadia C, Ma W L, Sadtler B, Alivisatos A P. Nano Lett, 2008, 8: 2551

[12] Choi S H, Kim E G, Hyeon T. J Am Chem Soc, 2006, 128: 2520

[13] Camacho-Bragado G A, Elechiguerra J L, Yacaman M J. Mater Character, 2008, 59: 204

[14] Pua F L, Chia C H, Zakaria S, Neoh S K, Liew T K. Sains Malaysiana, 2011, 40: 221

[15] Zou J, Zhang J X, Zhang B H, Zhao P T, Huang K X. Mater Lett, 2007, 61: 5029

[16] Ma L, Chen W X, Li H, Zheng Y F, Xu Z D. Mater Lett, 2008, 62: 797

[17] Sun Y F, Cheng H, Gao S, Sun Z H, Liu Q H, Liu Q Lei F C, Yao T, He J F, Wei S Q, Xie Y. Angew Chem Int Ed, 2012, 51: 8727

[18] Dai P C, Zhang G, Chen Y C, Jiang H C, Feng Z Y, Lin Z J, Zhan J H. Chem Commun, 2012, 48: 3006

Table 3

Comparison of efficiencies of present and previously reported catalysts.

\begin{tabular}{|c|c|c|c|c|c|c|}
\hline Entry & Catalyst & Solvent & Catalyst loading & Time (min) & Isolated yield (\%) & Ref. \\
\hline 1 & SnS-NPs@AC & EtOH, reflux & $5 \mathrm{~mol} \%$ & 20 & 91 & this work \\
\hline 2 & $\gamma$-Alumina & $\mathrm{H}_{2} \mathrm{O}$, reflux & $30 \mathrm{~mol} \%$ & 50 & 80 & [26] \\
\hline 3 & $\mathrm{H}_{14}\left[\mathrm{NaP}_{5} \mathrm{~W}_{30} \mathrm{O}_{110}\right]$ & EtOH, reflux & $1 \mathrm{~mol} \%$ & 55 & 93 & {$[27]$} \\
\hline 4 & PTSA & $\mathrm{H}_{2} \mathrm{O}$, reflux & $4 \mathrm{~mol} \%$ & 55 & 86 & {$[37]$} \\
\hline 5 & TEBA & $\mathrm{H}_{2} \mathrm{O}, 90^{\circ} \mathrm{C}$ & $0.15 \mathrm{~g}$ & 360 & 99 & [38] \\
\hline 6 & DBSA & $\mathrm{H}_{2} \mathrm{O}, 60^{\circ} \mathrm{C}$ & $10 \mathrm{~mol} \%$ & 180 & 88 & [39] \\
\hline 7 & SBPPSP & EtOH $/ \mathrm{H}_{2} \mathrm{O} / 100{ }^{\circ} \mathrm{C}$ & $0.05 \mathrm{~g}$ & 25 & 97 & {$[40]$} \\
\hline 8 & $\mathrm{SB}(\mathrm{DBU}) \mathrm{Cl}$ & EtOH, rt & $5 \mathrm{~mol} \%$ & 35 & 94 & {$[41]$} \\
\hline 9 & SB-DABCO & EtOH: $\mathrm{H}_{2} \mathrm{O}$, reflux & $6 \mathrm{~mol} \%$ & 30 & 86 & {$[42]$} \\
\hline
\end{tabular}




\section{Graphical Abstract}

Chin. J. Catal., 2015, 36: 626-633 doi: 10.1016/S1872-2067(14)60284-9

\section{Tin sulfide nanoparticles supported on activated carbon as an efficient and reusable Lewis acid catalyst for three-component one-pot synthesis of $4 \mathrm{H}$-pyrano[2,3-c]pyrazole derivatives}

Nasir Iravani*, Mosadegh Keshavarz*, Hossein Ali Shojaeian Kish, Rasool Parandvar Islamic Azad University, Iran; Yasouj University, Iran

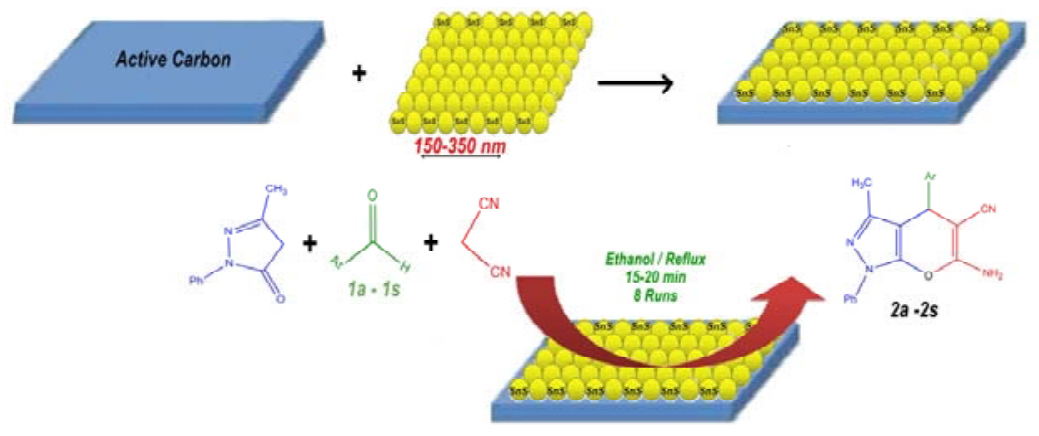

Tin sulfide nanoparticles immobilized on activated carbon were shown to be a powerful recoverable solid acid catalyst for the preparation of $4 H$-pyrano[2,3-c]pyrazole derivatives.

[19] Ramasamy K, Malik M A, O'Brien P. Chem Commun, 2012, 48: 5703

[20] Xin X K, He M, Han W, Jung J, Lin Z Q. Angew Chem Int Ed, 2011, 50: 11739

[21] Kuo S C, Huang L J, Nakamura H.J Med Chem, 1984, 27: 539

[22] Wang J L, Liu D X, Zhang Z J, Shan S M, Han X B, Srinivasula S M, Croce C M, Alnemri E S, Huang Z W. Proc Natl Acad Sci USA, 2000, 97: 7124

[23] Zaki M E A, Soliman H A, Hiekal O A, Rashad A E Z. Zeit Naturforsch C, 2006, 61: 1

[24] Zhu J P, Bienayme H (Eds). Multicomponent Reactions. Weinheim: Wiley-VCH, 2005

[25] Balaskar R S, Gavade S N, Mane M S, Shingate B B, Shingare M S, Mane D V. Chin Chem Lett, 2010, 21: 1175

[26] Mecadon H, Rohman M R, Kharbangar I, Laloo B M, Kharkongor I, Rajbangshi M, Myrboh B. Tetrahedron Lett, 2011, 52: 3228

[27] Heravi M M, Ghods A, Derikvand F, Bakhtiari K, Bamoharram F F. J Iran Chem Soc, 2010, 7: 615

[28] Vasuki G, Kumaravel K. Tetrahedron Lett, 2008, 49: 5636

[29] Gogoi S, Zhao C G. Tetrahedron Lett, 2009, 50: 2252

[30] Sheibani H, Babaie M. Synth Commun, 2010, 40: 257

[31] Ziarani G M, Abbasi A, Badiei A, Aslani Z. EJ Chem, 2011, 8: 293

[32] Gao S, Tsai C H, Tseng C, Yao C F. Tetrahedron, 2008, 64: 9143

[33] Fotouhi L, Heravi M M, Fatehi A, Bakhtiari K. Tetrahedron Lett, 2007, 48: 5379

[34] Azarifar D, Khatami S M, Nejat-Yami R. J Chem Sci, 2014, 126: 95

[35] Azarifar A, Nejat-Yami R, Al-Kobaisi M, Azarifar D. J Iran Chem Soc, 2013, 10: 439

[36] Khaksar S, Rouhollahpour A, Talesh S M. J Fluorine Chem, 2012, 141:11

[37] Heravi M M, Javanmardi N, Oskooei H A, Baghernejad B. GU J Sci, 2011, 24: 227

[38] Shi D Q, Mou J, Zuang Q Y, Niu L H, Wu N, Wang X S. Synth Commun, 2004, 34: 4557

[39] Jin T S, Zhao R Q Li T S. Arkivoc, 2006, (xi): 176
[40] Niknam K, Borazjani N, Rashidian R, Jamali A. Chin J Catal (催化学 报), 2013, 34: 2245

[41] Hasaninejad A, Golzar N, Beyrati M, Zare A, Doroodmand M M. J Mol Catal A, 2013, 372: 137

[42] Hasaninejad A, Shekouhy M, Golzar N, Zare A, Doroodmand M M. Appl Catal A, 2011, 402: 11

[43] Albadi J, Keshavarz M, Shirini F, Vafaee-nezhad M. Catal Commun, 2012, 27: 17

[44] Albadi J, Keshavarz M, Abedini M, Khoshakhlagh M. J Chem Sci, 2013, 125: 295

[45] Albadi J, Keshavarz M, Abedini M, Vafaee-nezhad M. Chin Chem Lett, 2012, 23: 797

[46] Keshavarz M, Iravani N, Ghaedi A, Ahmady A Z, Vafaei-Nezhad M, Karimi S. SpringerPlus, 2013, 2: 64

[47] Yavari I, Hajinasiri R, Sayyed-Alangi S Z, Iravani N. Monatsh Chem, 2008, 139: 1029

[48] Yavari I, Sanaeishoar T, Ghazvini M, Iravani N.J Sulfur Chem, 2010, 31: 169

[49] Iravani N, Safikhani Mohammadzade N, Niknam K. Chin Chem Lett, 2011, 22: 1151

[50] Iravani N, Karami B, Asadimoghaddam F, Monfared M, Karami N.J Sulfur Chem, 2012, 33: 279

[51] Iravani N, Albadi J, Varnaseri S, Jaberi Z, Karami N, Khadamati M. J Chin Chem Soc, 2012, 59: 1567

[52] Iravani N, Keshavarz M, Monfared M, Hosseini F. J Chin Chem Soc, 2014, 61: 357

[53] Nazari S, Keshavarz M, Karami B, Iravani N, Vafaee-Nezhad M. Chin Chem Lett, 2014, 25: 317

[54] Koktysh D S, McBride J R, Rosenthal S J. Nanoscale Res Lett, 2007, 2: 144

[55] Avellaneda D, Delgado G, Nair M T S, Nair P K. Thin Solid Films, 2007, 515: 5771

[56] Goudarzi A, Motedayen Aval G, Sahraei R, Ahmadpoor H. Thin Solid Films, 2008, 516: 4953 